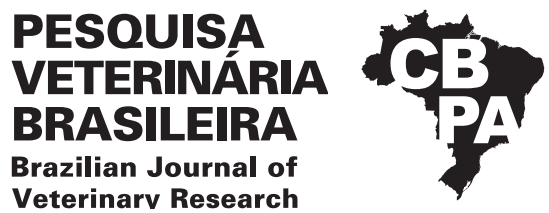

Pesq. Vet. Bras. 42:e06937, 2022

DOI: 10.1590/1678-5150-PVB-6937

Original Article

Livestock Diseases

ISSN 0100-736X (Print)

ISSN 1678-5150 (Online)

\title{
Accidental monensin poisoning in buffaloes in Bahia, Brazil $^{1}$
}

\author{
Antonio W.O. Silva ${ }^{2}$ (D) Múcio F.F. Mendonça² (D) Moisés D. Freitas ${ }^{3}$ (D), \\ Antonio L. Ribeiro Filho ${ }^{3}$ (D) Ricardo D.G. Silva ${ }^{3}$ (D) Paula V. Leal ${ }^{4}$ (D), \\ Luciano A. Pimentel ${ }^{5}$ (i) and Tiago C. Peixoto ${ }^{4 *}$ (D)
}

\begin{abstract}
Silva A.W.O., Mendonça M.F.F., Freitas M.D., Ribeiro Filho A.L., Silva R.D.G., Leal P.V., Pimentel L.A. \& Peixoto T.C. 2022. Accidental monensin poisoning in buffaloes in Bahia, Brazil. Pesquisa Veterinária Brasileira 42:e06937, 2022. Laboratório de Patologia Veterinária, Escola de Medicina Veterinária e Zootecnia, Universidade Federal da Bahia, Av. Adhemar de Barros 500, Salvador, BA 40170-110, Brazil. E-mail: tcpeixoto@ufba.br

Monensin is an ionophore antibiotic (IA) widely used for growth promotion and weight gain in the production of ruminants. However, it has caused intoxication in several species, including buffaloes, mainly because of the ignorance or disrespect of the recommendations for use in each animal species. The objective of this study was to describe, for the first time, clinical-epidemiological and anatomopathological data of an outbreak of accidental poisoning by monensin in buffalos and rediscuss the recommendation of the use of IA in the production of this species. The outbreak affected 21 adult buffaloes after consumption of remains from a feed formulated on the farm and whose constituents were mixed by hand. Clinical and first death signs were observed 24 hours after ingestion of this food. In general, the clinical picture was characterized by muscle weakness, tremors, difficulty in locomotion, and decubitus. Fifteen buffaloes presented clinical signs of poisoning $(71.5 \%$ morbidity), followed by death ( $100 \%$ lethality), after acute to subacute evolution $(<24 \mathrm{~h}$ to $96 \mathrm{~h}$ ). Laboratory tests indicated elevated serum activity of creatine phosphokinase and aspartate aminotransferase enzymes. Three buffaloes underwent necropsy, and samples from several organs were collected for histopathological examination. The main injuries found were hyaline degeneration and multifocal segmental necrosis in the skeletal and cardiac striated muscles (myopathy and degenerative-necrotic multifocal multifocal-necrotic cardiopathy). The diagnosis was confirmed by the toxicological evaluation of suspected ration remains, which detected $461.67 \mathrm{mg} / \mathrm{kg}$ of monensin. The death of $71.5 \%$ buffaloes in this lot occurred due to a succession of errors, which included faults in the formulation of the ration and, above all, due to the use of monensin in a highly sensitive species. Despite the possible beneficial effects of IA use as a dietary supplement for buffaloes, we are of the opinion that IAs should never be used in bubalinoculture since any increment in production does not compensate for the imminent risk of death due to a small safety margin for this species and the absence of antidotes.
\end{abstract}

INDEX TERMS: Ionophore antibiotics, buffaloes, monensin, iatrogenic intoxication, toxic myopathy, poisoning, necrotic myopathy, cardiomyopathy, Brazil.

\footnotetext{
${ }^{1}$ Received on June 9, 2021.

Accepted for publication on July 22, 2021.

Part of the Master's Thesis of the first author. CAPES Scholarship.

${ }^{2}$ Graduate Program in Animal Science in the Tropics (PPGCAT), Escola de Medicina Veterinária e Zootecnia (EMEVZ), Universidade Federal da Bahia (UFBA), Av. Adhemar de Barros 500, Salvador, BA 40170-110, Brazil.

${ }^{3}$ Departamento de Anatomia, Patologia e Clínicas Veterinárias, Escola de Medicina Veterinária e Zootecnia (EMEVZ), Universidade Federal da Bahia (UFBA), Av. Adhemar de Barros 500, Salvador, BA 40170-110, Brazil.
}

\footnotetext{
${ }^{4}$ Laboratório de Patologia Veterinária (LPV), Escola de Medicina Veterinária e Zootecnia (EMEVZ), Universidade Federal da Bahia (UFBA), Av. Adhemar de Barros 500, Salvador, BA 40170-110, Brazil. *Corresponding author: tcpeixoto@ufba.br

${ }^{5}$ Setor de Patologia Veterinária, Hospital Universitário de Medicina Veterinária, Universidade Federal do Recôncavo da Bahia (UFRB), Rua Rui Barbosa 710, Campus Universitário, Cruz das Almas, BA 44380-000, Brazil.
} 
RESUMO-- [Intoxicação acidental por monensina em búfalos na Bahia, Brasil.] Monensina é um antibiótico ionóforo (AI) amplamente empregado na produção de ruminantes para promoção de crescimento e ganho de peso, mas que tem causado intoxicação em diversas espécies, incluindo os búfalos, principalmente, pelo desconhecimento ou desrespeito das recomendações de uso e às particularidades de cada espécie animal. Objetivou-se descrever, pela primeira vez na Bahia, dados clínico-epidemiológicos e anatomopatológicos de um surto de intoxicação acidental por monensina em búfalos e rediscutir a recomendação do uso de AI na produção de bubalinos. 0 surto acometeu um lote de 21 búfalos adultos após consumo de sobras de uma ração para bovinos formulada na fazenda e cujos constituintes eram misturados à mão. Os sinais clínicos e primeiros óbitos foram observados 24 horas após a ingestão dessa ração. 0 quadro clínico, em geral, se caracterizou por fraqueza muscular, tremores, dificuldade de locomoção e decúbito. Quinze búfalos apresentaram sinais clínicos de intoxicação (morbidade 71,5\%), seguido de morte (letalidade $100 \%)$, após evolução aguda a subaguda $(<24 \mathrm{~h}$ até 96h). Exames laboratoriais indicaram acentuada elevação na atividade sérica das enzimas CPK e AST. Três búfalos foram necropsiados, sendo coletadas amostras de diversos órgãos para exame histopatológico. A principal lesão encontrada foi degeneração hialina e necrose segmentar multifocal nos músculos estriados esqueléticos e cardíacos (miopatia e cardiopatia degenerativo-necrótica tóxica multifocal polifásica). O diagnóstico foi confirmado pela avaliação toxicológica das sobras da ração suspeita, que detectou $461,67 \mathrm{mg} / \mathrm{kg}$ de monensina. A morte de 71,5\% dos búfalos deste lote ocorreu devido a uma sucessão de erros, que incluíram falhas na formulação da ração e, sobretudo, devido ao uso da monensina em uma espécie altamente sensível. Enfatizamos que, apesar dos possíveis efeitos benéficos do uso AIs como suplemento dietético para bubalinos, somos da opinião que os AIs nunca devem ser empregados na bubalinocultura, uma vez que os eventuais incrementos na produção não compensam o risco iminente de morte, devido a pequena margem de segurança para essa espécie e a inexistência de antídotos.

TERMOS DE INDEXAÇÃO: Antibióticos ionóforos, búfalos, monensina, intoxicação iatrogênica, miopatia tóxica, miopatia, cardiomiopatia necrótica, Brasil.

\section{INTRODUCTION}

Monensin is an ionophore (IA) polyether carboxylic antibiotic and a metabolite of the fermentation fungus Streptomyces cinnamonensis. IAs, such as monensin, salinomycin, narasin, and lasalocid, are used in the production systems of several species to control coccidiosis, including antimicrobials and growth promoters (Vieira et al. 2005).

IAs are safe drugs, if they are administered at the recommended dose for each species as there is considerable variation in sensitivity to these compounds depending on the species involved and the IA used (Nogueira et al. 2009). For buffaloes, the toxic dose of monensin is $5 \mathrm{mg} / \mathrm{kg}$ (Rozza et al. 2007), which is approximately four times lower than that for cattle, which varies between 22 and $50 \mathrm{mg} / \mathrm{kg}$ (Barros 2007). Equine species are particularly sensitive to monensin toxicity, which occurs after consumption of only $2-3 \mathrm{mg} / \mathrm{kg}$ of monensin (Bezerra Jr. et al. 2000), whereas in chickens, poisoning occurs after ingestion of $200 \mathrm{mg} / \mathrm{kg}$ of monensin (Hanrahan et al. 1981).

Cases of poisoning by IAs have been described in several species, such as horses (Pavarini et al. 2011, Sousa et al. 2019), cattle (Gava et al. 1997, Brito et al. 2020), sheep (Souza et al. 2008, França et al. 2009, Rissi \& Barros 2010), buffaloes (Rozza et al. 2006, Bence et al. 2018, Garcia et al. 2020), goats (Deljou et al. 2014), pigs (Miskimins \& Neiger 1996), canines (Segev et al. 2004), rabbits (Peixoto et al. 2009), chinchillas (Lucena et al. 2012), camels (Mousa \& El-Hamamsy 2013), collared peccaries (Ribeiro \& Santos 2016), and ostriches (Pavarini et al. 2011). Poisoning occurs due to accidental consumption of food with IAs, feed contamination, or incorrect use due to an error in either the calculation or the homogenization of the premix to the feed (França et al. 2009), by the concomitant use of drugs that potentiate the effects of IAs (Basaraba et al. 1999), or when inadvertently supplied to non-target species (Pavarini et al. 2011).

Cases of monensin poisoning in buffaloes are rare and, to date, there have been no reports from the northeast Brazil. In fact, in Brazil, only one outbreak in Rio Grande do Sul that occurred 14 years ago has been described (Rozza et al. 2006). Furthermore, in the international literature, two outbreaks of this nature have recently been described in Argentina (Bence et al. 2018, Garcia et al. 2020). This study aimed to describe the clinical, epidemiological and anatomopathological findings of an outbreak of accidental poisoning by monensin in buffaloes in the state of Bahia and to rediscuss the recommendations for the use of IAs in the production of this species.

\section{MATERIALS AND METHODS}

Historic and epidemiological data and information about the first clinical signs of monensin poisoning were obtained from the keeper and veterinarian responsible for the farm. This information was confirmed during two technical visits in loco on day 1 (D1) and D4 of the outbreak.

Physical examination was performed on seven animals after inspection of the buffalo herd. Blood samples were collected from nine adult female ruminants (6-12 buffaloes and two cows) in vacuum tubes containing a coagulation activator and separating gel (Vacutainer $\left.{ }^{\circledR}\right)$. The sera were obtained after clot retraction, centrifuged at $1200 \times \mathrm{g}$ for 10 min, placed in polyethylene microtubes (Eppendorf ${ }^{\circledR}$ ), and sent for measurement of serum creatine phosphokinase (CPK) and aspartate aminotransferase (AST) enzymes at the Clinical Analysis Laboratory of the "Hospital de Medicina Veterinária", "Universidade Federal da Bahia" (UFBA) and at the Vetanalises Laboratory, Salvador/BA. These examinations were performed in a semi-automatic biochemical analyzer BS $200{ }^{\circledR}$ and automatic PKL $125^{\circledR}$ using Bioclin ${ }^{\circledR}$ reagent.

Three adult buffaloes underwent necropsy: the sire (Buf-1) and two buffaloes (Buf-10 and 11) that died on D1, D3, and D4, respectively, after consumption of experimental feed for cattle formulated on the farm. Additionally, the Buf- 11 fetus, approximately 5 months old, was also necropsied. During necropsies, bilateral fragments of skeletal muscles (vastus intermedius, semimembranosus, and semitendinosus); central nervous system; and thoracic, abdominal, and pelvic organs were collected. This material was fixed in $10 \%$ formaldehyde, routinely processed using the paraffin embedding technique, cut into $5 \mu \mathrm{m}$ thick slices, and stained with hematoxylineosin (HE) at the Veterinary Pathology Laboratory at UFBA.

Samples of the leftovers of the feed supplied to the buffaloes on day zero (D0) were collected from the trough of the cattle and sent 
for toxicological evaluation (Fig.1) at CBO - Analyses Laboratorials Ltda. (Valinhos/SP) for qualitative and quantitative evaluation of IAs by high-performance liquid chromatography (HPLC) using the MA-198R0 method (AOAC 2005).

Additionally, to assess the occurrence of possible early degenerative lesions in the myocardium (cardiotoxic effect) of the fetus of Buf-11, who died of monensin, intoxication fragments of the fetal myocardium embedded in paraffin were sent to the Veterinary Pathology Department (SPV) from the "Universidade Federal do Rio Grande do Sul" (UFRGS) to perform immunohistochemistry (IHC) with anti-cardiac troponin $\mathrm{C}$ antibody (TncC) using a previously described technique (Pavarini et al. 2012).

\section{RESULTS}

In March 2019, an acute-to-subacute fatal disease affected a flock of 21 buffaloes (Lot 1 consisting of one male and 20 females) belonging to a herd of 50 adult Murrah buffaloes (Bubalus bubalis) aged five years and weighing $550 \mathrm{~kg}$ on average who were semi-extensively raised on a farm in the

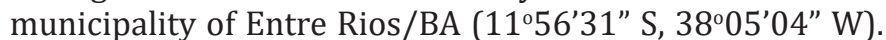
The buffaloes were kept in a pasture composed predominantly of Digitaria decumbens ("pangola grass") and, eventually, received complementary feeding, which varied according to availability on the school farm.

Herds of various species and breeds were kept on this property, including lactating Jersey cows, which comprised an experimental group aimed at evaluating feeding strategies and different ration compositions.

According to the history, the outbreak began one day after the change of the employee responsible for daily weighing the additives and mixing by hand in the concentrate of an experimental feed for eight Jersey cows in lactation. This ration consisted of corn silage, ground corn, wheat bran, soy, mineral salt, and sodium monensin (Poulcox $40^{\circledR}$ ). The latter, was added at the recommended dose of $24 \mathrm{mg} / \mathrm{kg}$ of dry matter and fed daily in the trough to the cows.

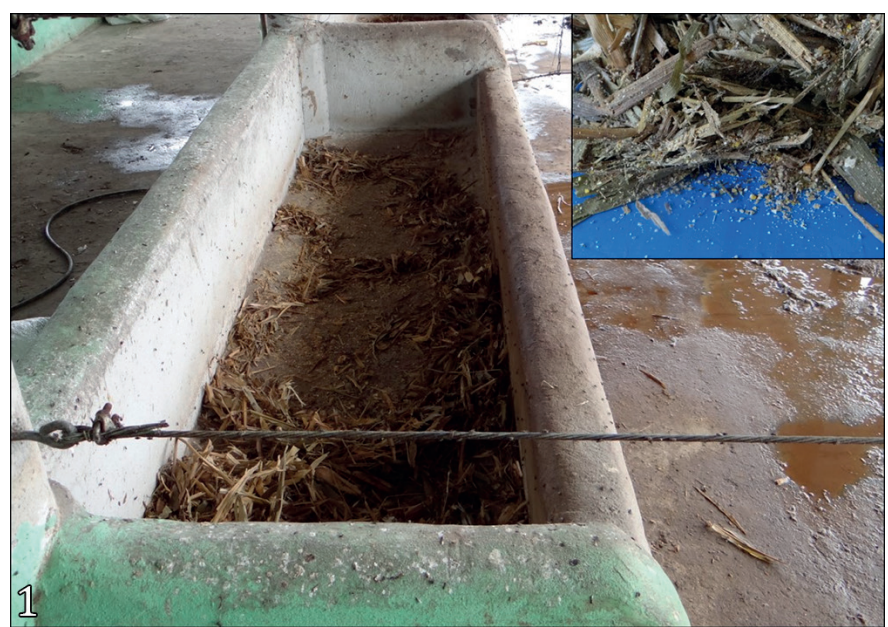

Fig.1. Outbreak of accidental monensin poisoning in buffaloes. Leftovers of the experimental feed for cattle formulated on the farm, which were collected from the trough and supplied in the pasture to the buffaloes of Lot 1. Inset: Sample of the feed collected from the trough and sent for toxicological evaluation. Entre Rios/BA.
On D0, the day before the appearance of the first clinical signs and/or onset of deaths, leftovers of the feed supplied to the cows were collected from the troughs and supplied to the buffaloes of Lot 1 . This act was recommended by the person responsible for formulating the food and aimed at complementing the buffalo's diet due to the lack of pastures. The daily use of leftovers from feeds formulated for cattle (experimental or not and with or without additives) was provided, whenever available, to buffaloes from Lot 1, without any complications. Thus, the volume and constituents of the leftovers supplied to the buffaloes were variable.

Approximately $24 \mathrm{~h}$ after consuming the remains of the experimental feed (morning of D1), the breeding buffalo (Buf-1) was found dead, with no premonitory signs. In addition, during the morning of D1, four buffaloes (Buf-2-5) exhibited ataxia, tremors, muscle weakness, walking dragging the pincers, and reluctance to move, followed by permanent sternal decubitus (Fig.2) and death during the afternoon of D1. Then, the first technical visit and necropsy of Buf- 1 were performed.

On this occasion, another four buffaloes (Buf-6-9) started showing a similar pattern. Clinically, Buf-6- 9 were conscious, had anorexia, semi-pasty stools, tachycardia (mean frequency: $84 \mathrm{bpm}$ ), tachypnea (mean frequency: $43 \mathrm{mpm}$ ), positive jugular pulse, congested mucosa, engorged episcleral vessels, and marked hyperthermia (mean rectal temperature: $40.8^{\circ} \mathrm{C}$ ). On D2, Buf-6-9 were found dead (up to 48h after consumption of leftover feed) and another six (Buf-10-15) started showing a similar clinical picture with a fatal outcome until D6.

In total, 15 buffaloes from Lot 1, including 21 animals, showed clinical signs of poisoning (morbidity: $71.5 \%$ ), followed

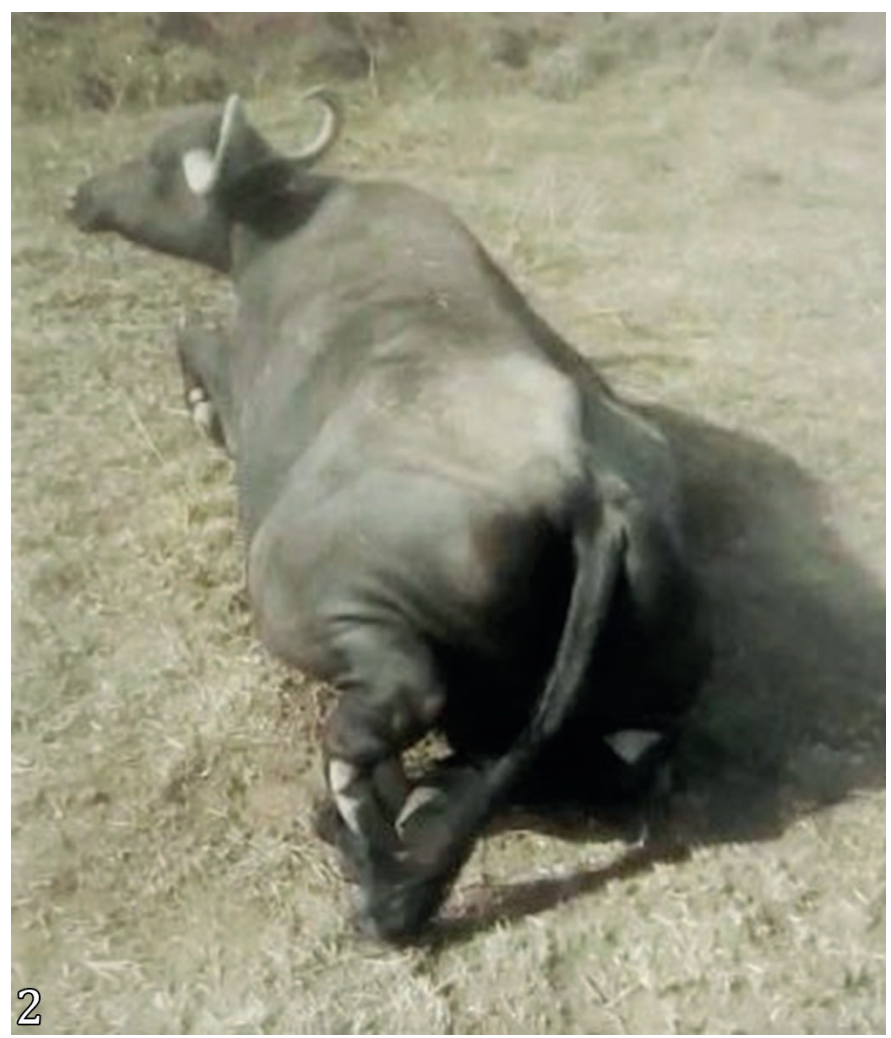

Fig.2. Outbreak of accidental monensin poisoning in buffaloes. Buffalo 2 in permanent sternal decubitus on day 1. Entre Rios/BA. 
by death $(100 \%$ lethality) within 6 days ( $<24$ to $144 \mathrm{~h}$ ) after consumption of leftovers from ration provided on D0, with acute to subacute evolution ( $<24$ to $96 \mathrm{~h}$ ). Additionally, on D1, two cows belonging to an experimental group including eight Jersey lactating cows receiving the same experimental feed showed clinical signs (morbidity: 25\%) similar to those observed in the poisoned buffaloes. However, clinical recovery was observed within $72 \mathrm{~h}$. This information is listed in Table 1.

The 29 buffaloes from the second lot, for which food was not provided, did not show any clinical changes. After Buf-1 was found dead on D1, the supply of leftovers from this food source to buffaloes was interrupted and, after the last death of the outbreak (D6), there were no new cases.

Biochemical tests revealed high serum CPK and AST activities in the seven buffaloes evaluated and in the two cows (except CPK from Bov-2), as shown in Table 2.

Necropsy of the three adult buffaloes (Buf-1, 10, and 11) revealed similar lesions, especially in the muscles of the pelvic limbs, heart, lungs, and liver. In Buf-1, only the skeletal muscles and heart were affected. The muscle lesions were bilaterally symmetrical and characterized by multiple pale areas (white or yellowish-white), focally extensive, well-defined, with irregular contours on the cut surface of the semimembranosus, semitendinosus, and vastus lateralis muscles of both pelvic limbs (Fig.3). Buf-10 showed marked myoglobinuria (Fig.4).

In the heart, there was marked multifocal (Buf-1 and 11) or diffuse (Buf-10) pallor of the left ventricle and interventricular septum (Fig.5). In addition, in Buf-10, 11 lesions secondary to acute heart failure were observed. In Buf-10, moderate hydropericardium $(500 \mathrm{ml})$ and a large cruoric clot in the left ventricular chamber was found, while in Buf-11 accentuated hydrothorax and ascites with fibrin filaments, moderate pulmonary congestion and edema, and mild focally extensive subcutaneous edema in the submandibular region were found.

Nonspecific changes included mild (Buf-10) to severe hepatomegaly (Buf-11), with evidence of a lobular pattern in addition to intense gallbladder distension, perirenal fat necrosis (Buf-11), multifocal endocardial suffusions (Buf-11), and moderate focal diaphragmatic hemorrhage (Buf-11).

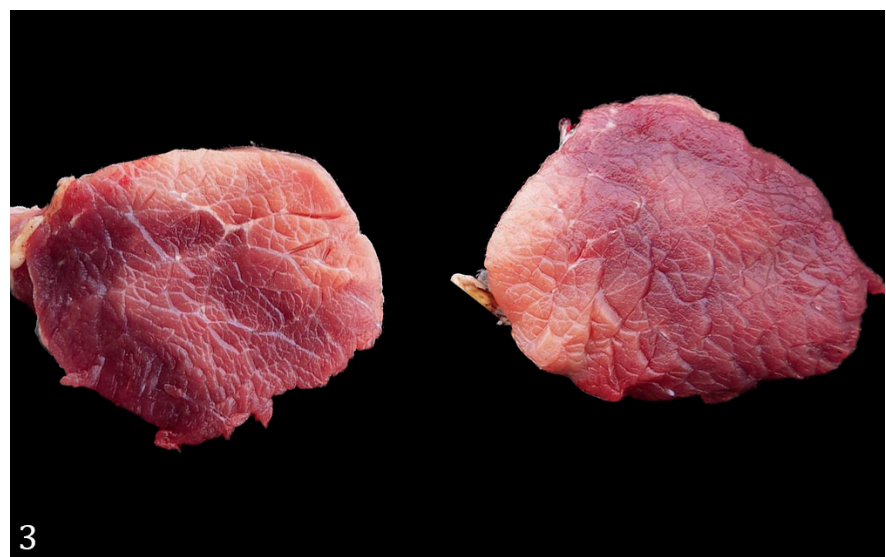

Fig.3. Outbreak of accidental monensin poisoning in buffaloes. Buffalo 10. Cutting surfaces of the right and left semitendinosus muscle showing symmetrical bilateral focal pallor. Day 4. Entre Rios/BA.

Table 1. Main data on the evolution and outcome of the outbreak of accidental monensin poisoning in buffaloes and cattle

\begin{tabular}{|c|c|c|c|c|}
\hline \multirow{2}{*}{$\begin{array}{c}\text { Ruminant } \\
\text { identification }\end{array}$} & \multirow{2}{*}{$\begin{array}{l}\text { Onset of clinical signs after } \\
\text { consumption of remains cattle feed }\end{array}$} & \multirow{2}{*}{ Clinical evolution } & \multicolumn{2}{|c|}{ Outcome } \\
\hline & & & Death & Recovery \\
\hline Buf-1 & Found dead $(<24 \mathrm{~h})$ & $<24 h$ & D1 & - \\
\hline Buf-2 a 5 & $<24 \mathrm{~h}$ & $\approx 6 \mathrm{~h}-12 \mathrm{~h}$ & D1 & - \\
\hline Buf-10 & & $\approx 12-24 \mathrm{~h}$ & D3 & - \\
\hline Buf-11 & $\sim 48 \mathrm{~b}$ & $\approx 48 \mathrm{~h}$ & D4 & - \\
\hline $\begin{array}{l}\text { Bov-1 } \\
\text { Bov-2 }\end{array}$ & $\approx 24 \mathrm{~h}$ & $\approx 72 \mathrm{~h}$ & - & D4 \\
\hline
\end{tabular}

Buf = buffalo, Bov = bovine.

Table 2. Changes in serum activity of CPK and AST enzymes in buffaloes and cows accidentally poisoned by monensin in Bahia state

\begin{tabular}{|c|c|c|c|c|}
\hline \multirow{2}{*}{ Ruminant identification } & \multirow{2}{*}{$\mathrm{CPK}(\mathrm{U} / \mathrm{L})$} & \multirow{2}{*}{$\operatorname{AST}(\mathrm{U} / \mathrm{L})$} & \multicolumn{2}{|c|}{ References } \\
\hline & & & $\mathrm{CPK}$ & AST \\
\hline Buf-6 & 5,420 & 414 & $14-177^{a}$ & $21-121^{a}$ \\
\hline Buf-7 & 1,680 & 186 & & \\
\hline Buf-8 & 439.5 & 311 & & \\
\hline Buf-9 & 2,138 & 192 & & \\
\hline Buf-10 & 12,600 & 403 & & \\
\hline Buf-11 & 488.7 & 192 & & \\
\hline Buf-12 & 412.4 & 305 & & \\
\hline Bov-1 & 870.6 & 208 & $35-280^{b}$ & $78-132^{b}$ \\
\hline Bov-2 & 229.1 & 197 & & \\
\hline
\end{tabular}

CPK = Creatine phosphokinase, AST = aspartate aminotransferase, Buf = buffalo, Bov = bovine; ${ }^{\text {a }}$ Ellah et al. $(2013),{ }^{b}$ Constable et al. $(2016)$. 
Histopathological examination revealed that the pale areas observed in the skeletal and cardiac musculature of the three adult buffaloes corresponded to areas of hyaline degeneration and multifocal segmental necrosis, which were characterized by hypercontracted, homogeneously eosinophilic fibers with vitreous and picnotic or absent nuclei (Fig.6 and 8) or by myocytes with eosinophilic cytoplasm and a floccular aspect (formation of eosinophilic cytoplasmic masses, occasionally vacuolated), compatible with degenerative-necrotic toxic multifocal polyphasic miopathy (Fig.7). Segmental fiber rupture was also observed. Occasionally, there was mild-to-moderate interstitial edema in the inflammatory infiltrate consisting of lymphocytes, plasma cells, and macrophages, especially in the vicinity of necrotic cardiomyocytes. Subepicardial hemorrhages (Buf-11) and thrombosis (Buf-10) were also observed.

In the liver, there was moderate(Buf-11) to severe (Buf10) centrilobular necrosis associated with congestion and hemorrhagic foci. Multifocal tubular vacuolization was observed in the kidneys, associated with dozens of brown refracting casts (myoglobinuric nephrosis) in the tubular lumen (Buf-10 and 11). No macroscopic or microscopic changes were observed in the Buf-11 fetus. Furthermore, IHC assessment did not show incipient cardiomyocyte necrosis (without reduced immunostaining with $\mathrm{TncC}$ ), a possible cardiotoxic effect of monensin.

The toxicological evaluation (HPLC) of leftover cattle feed formulated on the farm that was suspected to have caused the death of 15 buffaloes allowed the identification and quantification of the IA responsible for the poisoning. In this analysis, monensin was identified at a concentration of $461.67 \mathrm{mg} / \mathrm{kg}$.

\section{DISCUSSION AND CONCLUSIONS}

The diagnosis of monensin poisoning in buffaloes was established based on epidemiological, clinical, laboratory, and anatomopathological aspects and confirmed by toxicological examination, which detected a high level of monensin

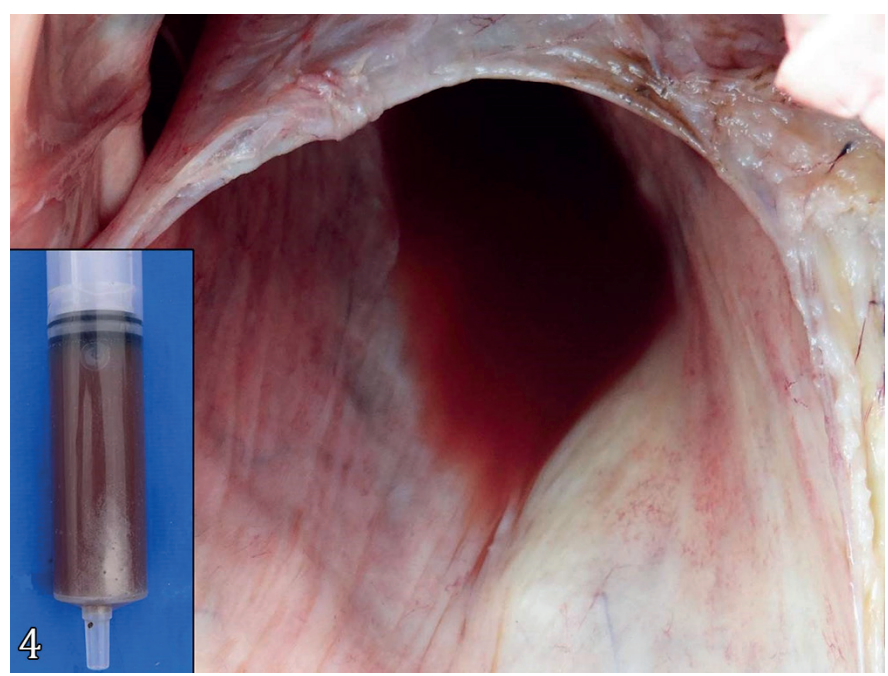

Fig.4. Outbreak of accidental monensin poisoning in buffaloes. Buffalo 10. Urine reddened in the bladder. Inset: syringe showing reddish urine (myoglobinuria). Day 4. Entre Rios/BA.
$(461.67 \mathrm{mg} / \mathrm{kg})$ in the leftovers of the experimental feed for cattle, formulated on the farm and supplied to buffaloes of Lot 1.

In relation to the monensin doses recommended for ruminants and those detected in the leftovers of the feed, some considerations are in order. For cattle, it is recommended that monensin be used as a growth promoter in doses of 16.5-33ppm (Barros 2007). Monensin was added at a dose of $24 \mathrm{mg} / \mathrm{kg}$ dry matter in the feed formulated for cattle on the farm. However, the toxicological examination of the leftovers of this feed detected $461.67 \mathrm{mg} / \mathrm{kg}$ of monensin, a concentration approximately 15 times that indicated for cattle, whose resistance to the toxic effects of monensin is at least four times greater than that of the buffaloes (Rozza et al. 2007). Under these conditions, considering the lethal dose of monensin for buffaloes ( $5 \mathrm{mg} / \mathrm{kg}$ body weight) (Rozza et al. 2007), the ingestion of 5.96kg of leftover feed (equivalent to $1.08 \%$ of its body weight) would be enough to cause the death of a $550 \mathrm{~kg}$ buffalo if the mixture of IA in the ration was homogeneous. However, given the probable failure to homogenize the experimental feed for the cows, later supplied to the buffaloes in Lot 1, even smaller amounts could have been fatal.

The difference about 15 to 20 times greater between the concentration of monensin detected by the toxicological examination in the leftovers of the experimental feed $(461.67 \mathrm{mg} / \mathrm{kg})$ and that recommended in its initial formulation $(24 \mathrm{mg} / \mathrm{kg}$ ) provides very strong circumstantial evidence of error in the weighing or mixing, by hand, of additives to the feed concentrate, formulated on the farm in D0, whose leftovers (source of poisoning) were supplied to the buffaloes of Lot 1 . The fact that two cows receiving the feed showed clinical signs on D1, like those manifested by poisoned buffaloes, reinforces this hypothesis. Apparently, monensin overdose is associated with a change in the person responsible for weighing and mixing the feed, which occurred precisely on D0.

Furthermore, it is likely that a failure to mix the IA with the roughage could also have occurred concurrently, resulting

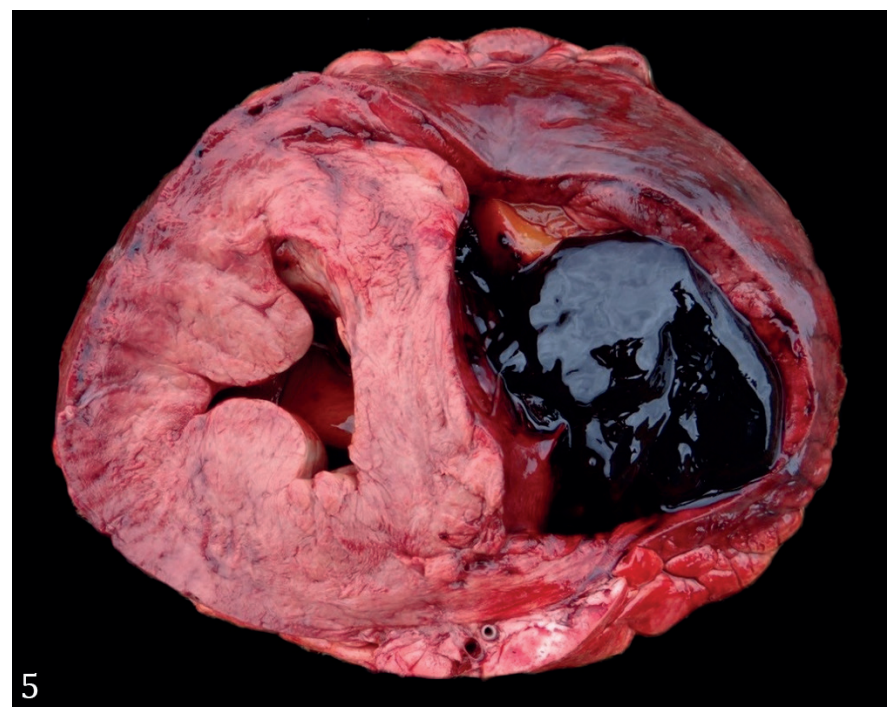

Fig.5. Outbreak of accidental monensin poisoning in buffaloes. Buffalo 10. Cross section of the heart. Note the marked diffuse pallor of the left ventricular myocardium and interventricular septum. Day 4. Entre Rios/BA. 
in an inhomogeneous mix. This would justify, among other factors, the variation in morbidity observed between cows $(25 \%, 2 / 8)$ and buffaloes $(71.5 \%, 15 / 21)$ and the time elapsed between feed intake on D0 and the onset of clinical signs $(<24$ to $48 \mathrm{~h}$ ) and evolution ( $<24$ to $96 \mathrm{~h}$ ) of poisoning in buffaloes.

Furthermore, considering the food management conditions used on the farm - supply of leftover cattle feed, in the pasture, to the 21 buffaloes of Lot 1 , and the existing food shortage, it is likely that the dominance of animals in the lot and voracity in consumption may have influenced the varied morbidity and evolution among buffaloes, due to differences in the amount ingested individually (Gava et al. 1997, Barros 2007). In fact,

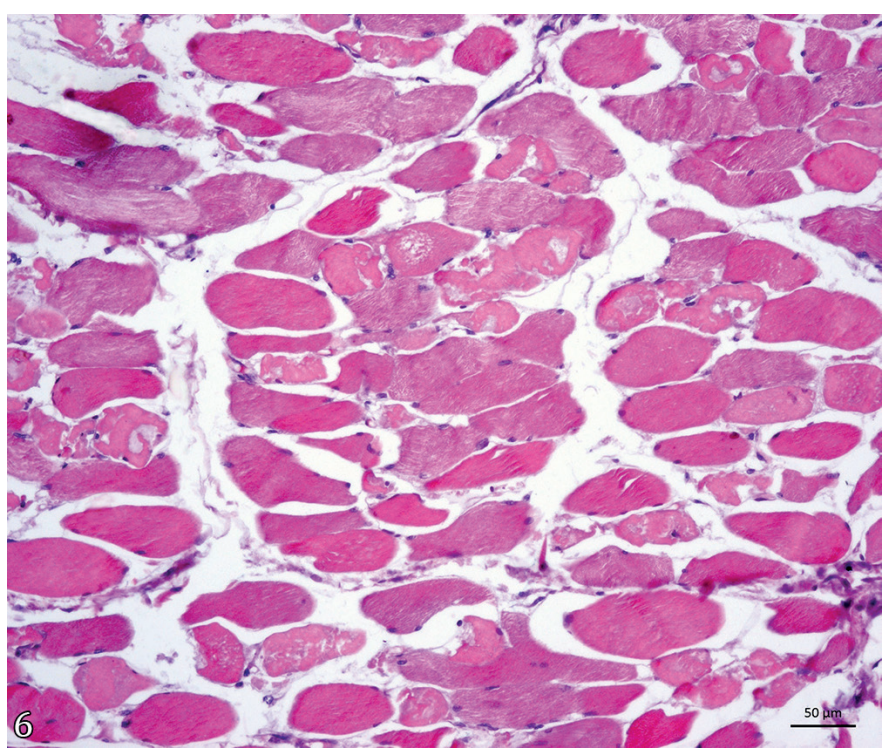

Fig.6. Outbreak of accidental monensin poisoning in buffaloes. Buffalo 1. Semitendinosus muscle, cross section. Hyaline degeneration and multifocal segmental necrosis. HE, obj.20x.

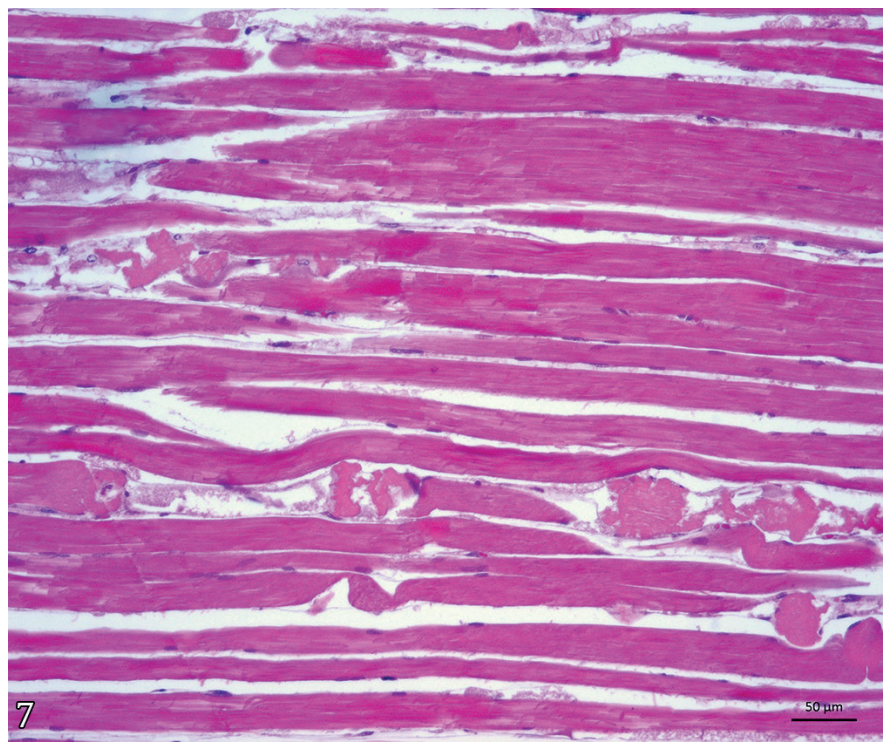

Fig.7. Outbreak of accidental monensin poisoning in buffaloes. Buffalo 1. Semitendinosus muscle, longitudinal section. Hyaline degeneration and segmental necrosis of muscle fibers, sometimes accompanied by lysis and fragmentation. HE, obj.10x. the breeding buffalo (Buf-1) and buffaloes with the best body condition scores (Buf-2 to 5) died within 24h after ingesting the remains of the bovine feed, while other buffaloes showed clinical evolution of up to $96 \mathrm{~h}$.

The rapid evolution of fatal poisoning by monensin observed in the buffaloes in this study, which had not been described for the species, called our attention. Rozza et al. (2007) experimentally reproduced monensin poisoning in buffaloes and observed that doses of 15 and $10 \mathrm{mg} / \mathrm{kg}$ induced animal death after a clinical evolution of four and 10 days, respectively. In the other descriptions of accidental poisoning in buffaloes by monensin, clinical evolutions of five-10 days have been reported (Rozza et al. 2006, Bence et al. 2018, Garcia et al. 2020). The high dose of monensin found in the feed fed to Lot 1 buffaloes may justify this unusual (hyperacute) evolution.

In the only accidental poisoning in buffaloes described so far in Brazil (Rozza et al. 2006), $90.7 \mathrm{mg} / \mathrm{kg}$ of monensin was detected in the feed considered the source of the poisoning. This concentration is five times lower than that found in the feed of this study, which may explain the lower morbidity $(25 \%, 40 / 160)$ and lethality $(25 \%, 10 / 40)$ observed by the authors, compared to those described here $(71.5 \%$ and $100 \%$, respectively). Similarly, in the recent outbreak of accidental monensin poisoning in buffaloes in Argentina (Garcia et al. 2020), which occurred after consumption of feed containing even lower doses of monensin $(65 \mathrm{mg} / \mathrm{kg})$, morbidity was also considerably lower $(17 \%, 30 / 174)$, although the mortality rate was $100 \%$. In both outbreaks, poisoning occurred after ingestion of a feed specifically formulated for cattle (Rozza et al. 2006, Garcia et al. 2020), an important epidemiological condition identical to that described here.

The amplitude of the variation in serum CPK activity among poisoned buffaloes (412.4-12,600U/L) and the lack of a correlation between the severity of the clinical picture and the outcome with this enzymatic variation must be emphasized. This finding was better evidenced when comparing the values

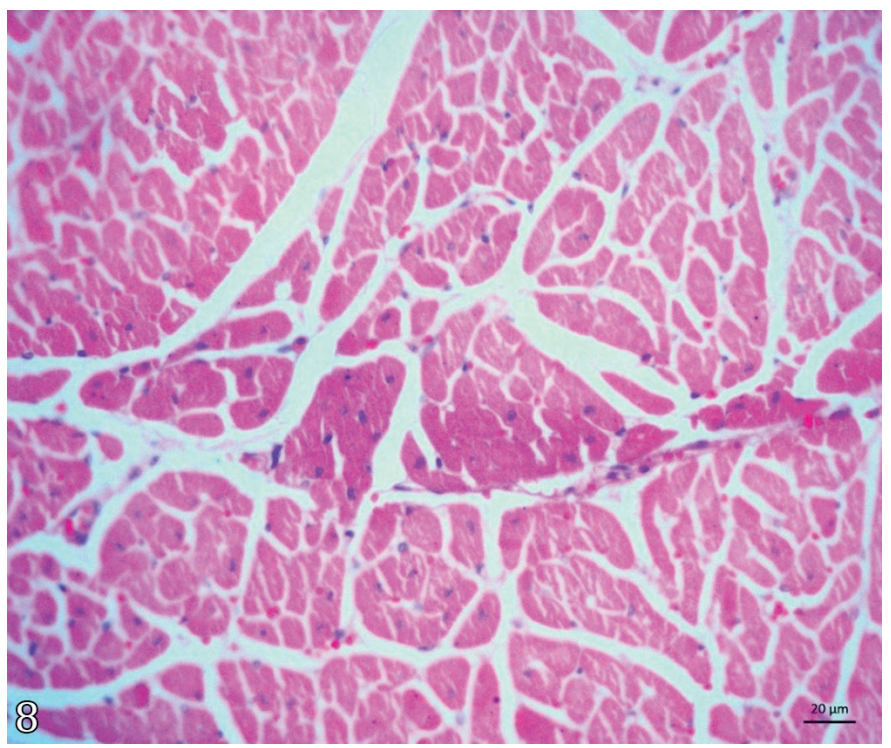

Fig.8. Outbreak of accidental monensin poisoning in buffaloes. Buffalo 1. Heart. Segmental necrosis of small groups of cardiomyocytes. HE, obj.40x. 
found between Buffaloes 8 (439.5U/L), 11 (488.7U/L) and 12 (412.4U/L) with Bovine $1(870.6 \mathrm{U} / \mathrm{L})$. This bovine, although showing an increase in CPK activity about four times the normal value, recovered, in contrast to Buffaloes 8,11 , and 12 , which, even with less accentuated elevations, even in proportional terms, died.

These findings demonstrate that, in fact, the differences in sensitivity between these species to IAs are remarkable and indicate that for cattle, the marked increase in CPK activity does not necessarily correlate with a poor prognosis and that, for buffaloes, the elevation of this enzyme may not be an ideal biomarker of muscle injury severity, in contrast to Rozza et al. (2007). According to these authors, CPK dosage may be useful in monitoring buffaloes that receive monensin in their diet. Furthermore, the results presented in two other outbreaks of monensin poisoning in buffaloes (Bence et al. 2018, Garcia et al. 2020) also reinforce our idea. Both Bence et al. (2018) and Garcia et al. (2020) observed a marked increase in serum CPK activity (836 to 10,847U/L and 641 $205 \mathrm{U} / \mathrm{L}$, respectively) in clinically healthy buffaloes, examined after ingestion of monensin in the diet. However, we must consider that Buffalo 10, which exhibited the greatest increase in serum CPK activity $(10,847 \mathrm{U} / \mathrm{L})$, was the only necropsied animal that presented with myoglobinuria, a lesion that denotes greater extension and severity of the muscle lesion, in agreement with the laboratory test results.

Monensin poisoning caused degenerative and necrotic changes in the myocardium and skeletal muscles in buffaloes in this study, similar to those reported in other studies with buffaloes (Rozza et al. 2006, 2007, Bence et al. 2018, Garcia et al. 2020) and, cattle (Gava et al. 1997, Brito et al. 2020), horses (Pavarini et al. 2011) and, sheep (Souza et al. 2008), given that only in the latter species, cardiac fibrosis has already been described (França et al. 2009).

As for striated musculature, there was no predominance of cardiac or musculoskeletal injuries or considerable variations in their intensity among buffaloes that died on the first (Buf1), third (Buf-10), or fourth day (Buf-11) of the outbreak. At present, these differences were slight. These findings are similar to those reported in the three bouts of accidental monensin poisoning in buffaloes (Rozza et al. 2006, Bence et al. 2018, Garcia et al. 2020). However, Rozza et al. (2007) experimentally demonstrated that there is a predominance of cardiac lesions in buffaloes $(80 \%, 4 / 5)$, but it is likely that this dissimilarity occurred because of the experimental design used by the authors, since buffaloes were confined in stalls, different from that occurring in accidental cases of poisoning, in which the movement of animals is not restricted.

It is hypothesized that such differences may be related to the pathogenesis of IA-induced muscle injury, which involves the action of catecholamines, calcium overload on myofibers, and the action of free radicals on membranes (Novilla 2018). In fact, the predominance of bilateral and symmetrical muscle injuries on muscles with higher demand (more susceptible to lipid peroxidation) is well known in nutritional myopathy due to selenium and vitamin E deficiency (Barros 2016). As for the lesion pattern in other species, Barros (2007) also highlighted that cattle and horses tend to have more marked lesions in the heart. However, this trend was not observed in later outbreaks of monensin poisoning in these species (Pavarini et al. 2011, Sousa et al. 2019, Brito et al. 2020).
Cavitary effusions and subcutaneous edema observed in Buf-10 and 11, attributed to cardiac involvement (toxic degenerative-necrotic alterations), can be explained by the longer evolution in these animals compared to Buf-1. In fact, in buffaloes (Rozza et al. 2007) and cattle (Wouters et al. 1997) experimentally poisoned by monensin and narasin, respectively, such lesions were only observed in animals that survived for $>60 \mathrm{~h}$ after IA consumption, which corroborates our findings.

Experimentally, it has been demonstrated in pregnant rats that nigericin, a type of polyether carboxylic IA, such as monensin, is able to induce reduced fetal growth and death in addition to malformations when administered at doses of 5 and $7.5 \mathrm{mg} / \mathrm{kg}$, between the 7 th and 11 th days of gestation (Vedel-Macrander \& Hood 1986). This demonstrates that compounds of this nature may be capable of causing fetal harm. However, in domestic animals, no references have been found regarding this occurrence. In fact, in our case, we did not observe macro, microscopic, or immunohistochemical alterations in the fetal myocardium. However, the absence of fetal lesions due to the acute clinical course (48h) of poisoning in Buf-11 cannot be ruled out.

In buffaloes, IA poisoning must be differentiated from rhabdomyolysis, a multifactorial disease recently described in buffaloes in Argentina (Llada et al. 2019), which is attributed to electrolyte imbalances and metabolic or mineral disorders and is often associated with excessive exercise (Cooper \& Valentine 2016, Llada et al. 2019). This disease has very similar clinical signs, biochemical alterations, and macroscopic and microscopic lesions and must be differentiated by the history of IA and toxicological tests.

For cattle, poisoning by IAs must be differentiated from other toxic myopathies and cardiomyopathies, particularly those caused by cardiotoxic plants that cause severe regressive changes and cardiac fibrosis, such as Niedenzuella multiglandulosa, Niedenzuella acutifolia (Caldas et al. 2011, Nascimento et al. 2018), and Ateleia glazioveana (Barros 2016); by plants that cause muscle degeneration and necrosis, such as Senna occidentalis (Carmo et al. 2011, Orlandini et al. 2015) and Senna obtusifolia (Carvalho et al. 2014); and nutritional myopathy (white muscle disease) caused by selenium and vitamin E deficiency (Barros et al. 1988, Barros 2007). Although, to date, such diseases have not been described in buffaloes, no toxic plants of these genera have been found in pastures where buffaloes from Lot 1 were kept.

Furthermore, in these cases, anatomopathological aspects allow this differentiation. In poisoning by Niedenzuella spp. and Ateleia glazioveana, musculoskeletal injuries do not occur, and the heart is the most affected organ (Gava et al. 2001, Stigger et al. 2001, Raffi et al. 2006, Caldas et al. 2011). The opposite is true for Senna spp. poisoning, in whic lesions are more pronounced in skeletal muscles and mild or absent in the myocardium (Barros et al. 1999, Carmo et al. 2011, Queiroz et al. 2012, Carvalho et al. 2014). In contrast, white muscle disease progresses with dystrophic mineralization in the myocardium and skeletal muscles (Barros et al. 1988, Amorim et al. 2005, Bezerra et al. 2007), an uncommon lesion in IA poisoning that was not observed in the present outbreak.

Unfortunately, the outbreak described here was attributed to a likely succession of errors, which included overdosing due to miscalculation, weighing, and homogenization of the premix to the on-farm feed and, above all, due to the use of 
monensin for non-target and sensitive species to IA. According to Pavarini et al. (2011), the use of feed for non-target species is, if not the most frequent, one of the main causes of poisoning by IAs. This succession of errors culminated in the death of nearly three-quarters of the buffalo flock $(71.5 \%, 15 / 21)$, including the only breeder in the squad.

This fact shows that, even today, there is a mistaken extrapolation of knowledge about the demands of the bovine species such as buffalo, although the toxic dose of monensin for buffaloes has already been experimentally determined for over 14 years (Rozza et al. 2007) and the sensitivity of buffaloes to monensin is four times greater than that of cattle (Rozza et al. 2006, 2007). It is evident, therefore, that there is great misunderstanding about the recommended doses of IAs for each species of production animal, which reinforces the importance of the extension service (continuing education) offered by the "Centro de Desenvolvimento da Pecuária" (Center for the Development of Livestock) of the "Universidade Federal da Bahia" (CDP-UFBA) to producers in the state in an attempt to avoid the occurrence of management errors, which can have a mortality rate of up to $100 \%$, as in the outbreak described here.

It is noteworthy that, after the ban on the supply of feed for non-target species on the farm where the outbreak occurred, until today (about two years later), new cases of poisoning by IAs have not been observed. It is worth remembering that Borges et al. (2001), about 20 years ago, already warned that IAs should never be added to the feed of horses (a particularly sensitive species) as only $2-3 \mathrm{mg} / \mathrm{kg}$ of monensin is fatal for the species (Bezerra Jr. et al. 2000). Despite the beneficial effects of using IAs as a dietary supplement for buffaloes (Andrighetto et al. 2005) and the recommendation to use them with great caution by some authors (Rozza et al. 2006, Garcia et al. 2020), we are extremely against recommending its use in buffaloes considering that the single dose capable of causing buffalo death is also very low ( $5 \mathrm{mg} / \mathrm{kg}$ ) (Rozza et al. 2007).

Thus, it is evident that the safety margin, a pharmacodynamic indicator that expresses the difference between the lethal dose and the effective dose of the drug, of IA for buffaloes is small. Furthermore, since there are no specific antidotes or treatments for IA poisoning, its prevention must be prioritized. Thus, we believe that IAs should not be used in the production of buffaloes since any increase in production does not compensate for the imminent risk of death.

Acknowledgments.- This study was financed in part by the "Coordenação de Aperfeiçoamento de Pessoal de Nível Superior (CAPES)”, Brazil, Finance Code 001. The authors would like to thank Professors Dr. Saulo Pavarini and Dr. David Driemeier (UFGRS) by assisting with anti-cardiac troponin C immunehistochemistry.

Conflict of interest statement.- The authors declare no conflicts of interest.

\section{REFERÊNCIAS}

Amorim S.L., Oliveira A.C.P., Riet-Correa F., Simões S.V.D., Medeiros R.M.T. \& Clementino I.J. 2005. Distrofia muscular nutricional em ovinos na Paraíba. Pesq. Vet. Bras. 25(2):120-124. <https://dx.doi.org/10.1590/ S0100-736X2005000200010>

Andrighetto C., Jorge A.M., Gomes M.I.F.V., Hoch A. \& Piccinin A. 2005. Efeito da monensina sódica sobre a produção e composição do leite, a produção de mozzarela e o escore de condição corporal de búfalas Murrah. Revta Bras. Zootec. 34(2):641-649. <https://dx.doi.org/10.1590/S151635982005000200034>
AOAC 2005. Method 2006.01, Chapter 5:51. Official Methods of Analysis, Association of Official Analytical Chemists.

Barros C.S.L. 2007. Intoxicação por antibióticos ionóforos, p.45-50. In: Riet-Correa F., Schild A.L., Lemos R.A.A. \& Borges J.R.J. (Eds), Doenças de Ruminantes e Equídeos. Vol.2. 3⿳ㅗㄹ. ed. Pallotti, Santa Maria, RS.

Barros C.S.L. 2016. Sistema muscular, p.1068-1128. In: Santos R.L. \& Alessi A.C. (Eds), Patologia Veterinária. 2ª ed. Roca, Rio de Janeiro, RJ.

Barros C.S.L., Barros S.S., Santos M.N. \& Metzdorf L.L. 1988. Miopatia nutricional em bovinos no Rio Grande do Sul. Pesq. Vet. Bras. 8(3/4):51-55.

Barros C.S.L., Ilha M.R.S., Bezerra Jr. P.S., Langohr I.M. \& Kommers G.D. 1999. Intoxicação por Senna occidentalis (Leg. Caesalpinoideae) em bovinos em pastoreio. Pesq. Vet. Bras. 19(2):68-70. <https://dx.doi.org/10.1590/ s0100-736x1999000200003>

Basaraba R.J., Oehme F.W., Vorhies M.W. \& Stokka G.L. 1999. Toxicosis in cattle from concurrent feeding of monensin and dried distiller's grains contaminated with macrolide antibiotics. J. Vet. Diagn. Invest. 11(1):79-86. <https://dx.doi.org/10.1177/104063879901100113><PMid:9925217>

Bence A.R., Garcia J., Fernandez E., Morrell E. \& Canton G. 2018. Hallazgos clínico-patológicos compatibles con intoxicación con ionóforos en búfalas: primer reporte en Argentina. Revta Vet. 29(2):79-82. <https://dx.doi. org/10.30972/vet.2923268>

Bezerra F.S.B., Batista J.S., Melo D.E.B., Lima Neto E.S. \& Farias Y.J.M.D. 2007. Miopatia nutricional em ovinos no Rio Grande do Norte. Acta Vet. Bras. 1(2):60-63. <https://dx.doi.org/10.21708/avb.2007.1.2.400>

Bezerra Jr. P.S., Ilha M.R.S., Langohr I.M. \& Barros C.S.L. 2000. Intoxicação experimental por monensina em equinos. Pesq. Vet. Bras. 20(3):102-108. <https://dx.doi.org/10.1590/s0100-736x2000000300003>

Borges A.S., Silva D.P.S., Gonçalves R.C., Kuchembuck M.R.G., Chiacchio S.B., Mendes L.C.N \& Bandarra E.P. 2001. Ionóforos e equinos: uma combinação fatal. Revta Educ. Cont. CRMV-SP 4(2):33-40.<https://dx.doi.org/10.36440/ recmvz.v4i2.3316>

Brito E.S.A., Andrade T.G., Oliveira C.H.S. \& Moura V.M.D.B. 2020. Outbreak of monensin poisoning in cattle due to supplementation error. Ciência Rural 50(11):1-5. <https://dx.doi.org/10.1590/0103-8478cr20190996>

Caldas S.A., Peixoto T.C., Nogueira V.A., França T.N., Tokarnia C.H. \& Peixoto P.V. 2011. Aborto em bovinos devido à intoxicação por Tetrapterys acutifolia (Malpighiaceae). Pesq. Vet. Bras. 31(9):737-746. <https://dx.doi. org/10.1590/s0100-736x2011000900003>

Carmo P.M.S., Irigoyen L.F., Lucena R.B., Fighera R.A., Kommers G.D. \& Barros C.S.L. 2011. Spontaneous coffee Senna poisoning in cattle: report on 16 outbreaks. Pesq. Vet. Bras. 31(2):139-146. <https://dx.doi.org/10.1590/ s0100-736x2011000200008>

Carvalho A.Q., Carvalho N.M., Vieira G.P., Santos A.C., Franco G.L., Pott A., Barros C.S.L. \& Lemos R.A.A. 2014. Intoxicação espontânea por Senna obtusifolia em bovinos no Pantanal Sul-Mato-Grossense. Pesq. Vet. Bras. 34(2):147-152.<https://dx.doi.org/10.1590/s0100-736x2014000200009>

Constable P.D., Hinchcliff K.W., Done S.H. \& Grunberg W. 2016. Veterinary Medicine: a textbook of the diseases of cattle, horses, sheeps, pigs and goats. 11th ed. Saunders Ltd., Saint Louis, p.2217-2219.

Cooper B.J. \& Valentine B.A. 2016. Muscle and tendon, p.165-249. In: Maxie M.G. (Ed). Jubb, Kennedy, and Palmer's Pathology of Domestic Animals. Vol.1. 6th ed. Elsevier, Saint Louis.

Deljou M., Aslani M.R., Mohri M., Movassaghi A.R. \& Heidarpour M. 2014. Clinical, laboratory and pathological findings in sub-acute monensin intoxication in goats. Vet. Res. Forum 5(3):161-167. <PMid:25568713>

Ellah M.R.A., Hamed M.I. \& Derar R.I. 2013. Serum biochemical and hematological reference values for lactating buffaloes. Comp. Clin. Pathol. 23(5):11791188. <https://dx.doi.org/10.1007/s00580-013-1760-2> 
França T.N., Nogueira V.A., Yamasaki E.M., Caldas S.A., Tokarnia C.H. \& Peixoto P.V. 2009. Intoxicação acidental por monensina em ovinos no Estado do Rio de Janeiro. Pesq. Vet. Bras. 29(9):743-746. <https://dx.doi.org/10.1590/ s0100-736x2009000900011>

Garcia E.N., Pistán M.E., Lértora W.J., Mastrantonio G.E. \& Cholich L.A. 2020. Monensin poisoning in buffalo feedlot from Argentina. Revta Vet. 31(1):3841. <https://dx.doi.org/10.30972/vet.3114616>

Gava A., Barros C.S.L., Pilati C., Barros S.S. \& Mori A.M. 2001. Intoxicação por Ateleia glazioviana (Leg. Papilionoideae) em bovinos. Pesq. Vet. Bras. 21(2):49-59. <https://dx.doi.org/10.1590/s0100-736x2001000200003>

Gava A., Wouters A.T.B., Wouters F., Nizgoski L. \& Barros C.S.L. 1997. Intoxicação por salinomicina em bovinos. Pesq. Vet. Bras. 17(3/4):127-130. <https:// dx.doi.org/10.1590/s0100-736x1997000300007>

Hanrahan L.A., Corrie D.E. \& Naqi S.A. 1981. Monensin toxicosis in broiler chickens. Vet. Pathol.18(5):665-671.<https://dx.doi.org/10.1177/030098588101800511> <PMid:7281463>

Llada I., Gianechini L.S., Odriozola E., Brambilla E., Fernandez E., Scioli V., Canton G. \& Morrell E. 2019. Rhabdomyolysis in water buffaloes (Bubalus bubalis). Braz.J.Vet. Pathol. 12(3):139-143.<https://dx.doi.org/10.24070/ bjvp.1983-0246.v12i3p139-143>

Lucena R.B., Fighera R.A., Tessele B., Giaretta P.R. \& Barros C.S.L. 2012. Surtos de intoxicação por salinomicina em chinchilas (Chinchilla lanigera). Pesq. Vet. Bras. 32(1):43-48. <https://dx.doi.org/10.1590/s0100736x2012000100008>

Miskimins D.W. \& Neiger R.D. 1996. Monensin toxicosis in swine.J. Vet. Diagn. Invest. 8(3):396-397. <https://dx.doi.org/10.1177/104063879600800324> <PMid:8844591>

Mousa S.A. \& El-Hamamsy H.T. 2013. Monensin toxicosis in camels reared in Egypt: updating clinical and clinicopathological investigations. J. Anim. Sci. Adv. 3(10):551-558.

Nascimento N.C.F., Aires L.D.A., Pfister J.A., Medeiros R.M.T., Riet-Correa F. \& Mendonça F.S. 2018. Plantas cardiotóxicas para ruminantes no Brasil. Pesq. Vet. Bras. 38(7):1239-1249. <https://dx.doi.org/10.1590/16785150-pvb-5548>

Nogueira V.A., França T.N. \& Peixoto P.V. 2009. Intoxicação por antibióticos ionóforos em animais. Pesq. Vet. Bras. 29(3):191-197. <https://dx.doi. org/10.1590/s0100-736x2009000300001>

Novilla M.N. 2018. Ionophores, p.1073-1092. In: Gupta R.C. (Ed.), Veterinary Toxicology: basic and clinical principles. 3rd ed. Academic Press, Massachusetts. <https://dx.doi.org/10.1016/B978-0-12-811410-0.00078-7>

Orlandini C.F., Alberton L.R., Boscarato A.G., Steiner D., Marins W.C., Mello P.V.B. \& Ribeiro R.C.L. 2015. Intoxicação espontânea por Senna occidentalis em bovino no Estado do Paraná, Brasil. Acta Scient. Vet. 43(Supl.1):88.

Pavarini S.P., Bandinelli M.B., Juffo G.D., Souzar S.O., Driemeier D. \& Cruz C.E.F. 2012. Decreased expression of cardiac troponin $C$ is associated with cardiac lesions in Amorimia exotropica poisoned cattle. Pesq. Vet. Bras. 32(10):10051008. <https://dx.doi.org/10.1590/s0100-736x2012001000010>

Pavarini S.P., Wouters F., Bandarra P.M., Souza F.S., Dalto A.G.C., Gomes D.C., Cruz C.E.F. \& Driemeier D. 2011. Surto de intoxicação por monensina em avestruzes e equinos no sul do Brasil. Pesq. Vet. Bras. 31(10):844-850. <https://dx.doi.org/10.1590/s0100-736x2011001000003>
Peixoto P.V., Nogueira V.A., González A.P., Tokarnia C.H. \& França T.N. 2009. Accidental and experimental salinomycin poisoning in rabbits. Pesq. Vet. Bras. 29(9):695-699. <https://dx.doi.org/10.1590/s0100-736x2009000900002>

Queiroz G.R., Ribeiro R.C.L., Romão F.T.N.M.A., Flaiban K.K.M.C., Bracarense A.P.F.R.L. \& Lisboa J.A.N. 2012. Intoxicação espontânea de bovinos por Senna obtusifolia no estado do Paraná. Pesq. Vet. Bras. 32(12):1263-1271. <https://dx.doi.org/10.1590/s0100-736x2012001200009>

Raffi M.B., Rech R.R., Sallis E.S.V., Rodrigues A. \& Barros C.S.L. 2006. Chronic cardiomyopathy and encephalic spongy changes in sheep experimentally fed Ateleia glazioviana. Ciência Rural 36(6):1860-1866. <https://dx.doi. org/10.1590/s0103-84782006000600030>

Ribeiro V.M.F. \& Santos F.G.A. 2016. Alterações clínicas e anatomopatológicas produzidas por intoxicação acidental com salinomicina sódica em catetos (Tayassu tajacu). Revta Bras. Med. Vet. 38(1):69-72.

Rissi D.R. \& Barros C.S.L. 2010. Intoxicação espontânea por antibióticos ionóforos em ovinos no Rio Grande do Sul. Pesq. Vet. Bras. 30(3):219-221. <https://dx.doi.org/10.1590/s0100-736x2010000300005>

Rozza D.B., Correa A.M.R., Leal J.S., Bandarra P.M., Guagnini F.S., Raymundo D.L. \& Driemeier D. 2007. Intoxicação experimental por monensina em búfalos e bovinos. Pesq. Vet. Bras. 27(4):172-178. <https://dx.doi.org/10.1590/ S0100-736X2007000400008>

Rozza D.B., Vervuert I., Kamphuers J., Cruz C.E.F. \& Driemeier D. 2006. Monensin toxicosis in water buffaloes (Bubalus Bubalis). J. Vet. Diagn. Invest. 18(5):494-496. <https://dx.doi.org/10.1177/104063870601800515> <PMid:17037623>

Segev G., Baneth G., Levitin B., Aroch I. \& Shlosberg I. 2004. Accidental poisoning of 17 dogs with lasalocid. Vet. Rec. 155(6):174-176. <https:// dx.doi.org/10.1136/vr.155.6.174><PMid:15357378>

Sousa D.E.R., Costa M.M., Ferreira Jr. J.A., Wilson T.M., Nascimento K.A., Pedroso P.M.O. \& Macedo J.T.S.A. 2019. Surto de intoxicação por monensina sódica em equinos associada a consumo de suplemento mineral à base de melaço de cana-de-açúcar. Acta Scient. Vet. 47(Supl.1):363. <https:// dx.doi.org/10.22456/1679-9216.89523>

Souza T.S., Costa J.N., Silva A.E., Moreira E.L.T., Ferreira M.M. \& Costa A.F. 2008. Intoxicação por monensina em ovinos. Arch. Vet. Sci. 13(4):280-284. $<$ https://dx.doi.org/10.5380/avs.v13i4.15274>

Stigger A.L., Barros C.S.L., Langohr I.M. \& Barros S.S. 2001. Intoxicação experimental por Ateleia glazioviana (Leg. Papilionoideae) em ovinos. Pesq. Vet. Bras. 21(3):98-108. <https://dx.doi.org/10.1590/s0100736x2001000300002>

Vedel-Macrander G.C.V. \& Hood R.D. 1986. Teratogenic effects of nigericin, a carboxylic ionophore. Teratology 33(1):47-51. <https://dx.doi.org/10.1002/ tera.1420330108><PMid:3738809>

Vieira L.S., Lobo R.N.B., Barros N.N., Portela C.H.P. \& Simplicio A.A. 2005. Monensina sódica no controle da eimeriose em caprinos leiteiros. Ciênc. Anim. 15(1):25-31.

Wouters A.T.B., Wouters F. \& Barros C.S.L. 1997. Intoxicação experimental por narasina em bovinos. Pesq. Vet. Bras. 17(2):82-88. <https://dx.doi. org/10.1590/s0100-736x1997000200007> 